\title{
Jumlah konsumsi dan metode memasak ikan terhadap kejadian dislipidemia
}

\author{
Quantity of fish consumption and the cooking method with incidence of dyslipidemia
}

Farida Nailufar ${ }^{1}$, Martalena Br Purba ${ }^{2}$, Emy Huriyati ${ }^{3}$

\begin{abstract}
Background: Some studies state that fish consumption of at least 200-400 g/week can reduce the risk of coronary heart disease. Omega 3 polyunsaturated fatty acids in fish have cardioprotective effects. However, the cardiac effect of fish consumption are not primarily related to the amount of fish consumed but also its cooking method. The cooking method (eg, frying) may alter the fatty acid content of a fish meal by absorbing fatty acids from cooking oils and adding trans fatty acids. Non-fried fish consumption (eg, boiled/steamed) was associated with lower risk of coronary heart disease but fried fish was not. Objective: To identify the quantity of fish consumed and the cooking method with the incidence of dyslipidemia. Method: The study was observational with case control design in patients that checked themselves at Prodia laboratory of Samarinda. Respondents consisted of 152 patients, comprising 76 cases and 76 control. Cases were patients with dyslipidemia and control were those without dyslipidemia matched according to gender and age. Analysis used Chi-Square statistical test at confidence interval 95\%. Results: There was significant difference in

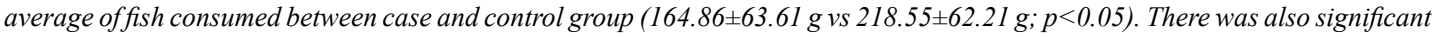
difference $(p<0.05)$ between case and control group in variables of body mass index $\left(24.53 \pm 2.4 \mathrm{~kg} / \mathrm{m}^{2} \mathrm{vs} 23.26 \pm 1.6 \mathrm{~kg} / \mathrm{m}^{2}\right) ; \mathrm{intake}$ of saturated fatty acids (SFA) (34.58 $\pm 5.82 \mathrm{~g} v \mathrm{~s} 28.27 \pm 5.4 \mathrm{~g})$; simple carbohydrate (63.86 $\pm 13.67 \mathrm{~g} v \mathrm{~s} 49.35 \pm 11.81 \mathrm{~g})$; fruit and vegetable $(42.61 \pm 20.17 \mathrm{~g}$ vs $53.48 \pm 23.47 \mathrm{~g})$; and waist circumference $(88.88 \pm 9.08 \mathrm{~cm} v \mathrm{~s} 86.21 \pm 7.8 \mathrm{~cm})$. In the final multivariate analysis, quantity of fish consumed has no influences with dyslipidemia $(p>0,05)$, but the influence is in the cooking method process $(O R=10,84 ; p<0,05)$. Conclusion: There was no influence between quantity of fish consumption. Risk for the prevalence of dyslipidemia was 10,84 times greater in the subject who the cooking method does not suitable the recommendation.
\end{abstract}

KEY WORDS: fish, consumption, omega 3, cooking method, dyslipidemia

\begin{abstract}
ABSTRAK
Latar belakang: Beberapa penelitian menyatakan bahwa konsumsi ikan sedikitnya 200-400 g/minggu dapat menurunkan risiko terkena serangan jantung. Omega 3 yang terdapat pada ikan dapat mencegah penyakit jantung dan penyakit degeneratif lainnya Namun, konsumsi ikan yang tinggi dan diolah dengan cara yang salah tidak menunjukkan adanya hubungan dengan penurunan risiko penyakit jantung. Metode menggoreng menyebabkan terserapnya minyak goreng di dalam daging ikan dan lemak ikan justru terbuang keluar selama proses penggorengan karena asam lemak omega 3 mudah sekali mengalami kerusakan akibat pemanasan seperti penggorengan akibat proses oksidasi. Tujuan: Mengetahui pengaruh jumlah konsumsi dan metode memasak ikan terhadap kejadian dislipidemia. Metode: Penelitian ini merupakan penelitian observasional dengan rancangan penelitian kasus kontrol pada pasien yang memeriksakan dirinya di Laboratorium Prodia Samarinda. Jumlah subjek sebesar 152 pasien yang terdiri dari 76 kasus dan 76 kontrol. Kasus adalah penyandang dislipidemia dan kontrol adalah bukan penyandang dislipidemia yang disetarakan berdasarkan jenis kelamin dan usia. Uji statistik yang digunakan adalah uji Chi-Square dengan tingkat kepercayaan 95\%. Hasil: Terdapat perbedaan bermakna rerata jumlah konsumsi ikan antara kasus dan kontrol $(164,86 \pm 63,61 \mathrm{~g}$ vs $218,55 \pm 62,21 \mathrm{~g} ; \mathrm{p}<0,05)$ Perbedaan yang bermakna antara kasus dan kontrol juga terlihat pada variabel IMT $\left(24,53 \pm 2,4 \mathrm{~kg} / \mathrm{m}^{2} \mathrm{vs} 23,26 \pm 1,6 \mathrm{~kg} / \mathrm{m}^{2}\right)$; asupan SFA $(34,58 \pm 5,82 \mathrm{~g}$ vs $28,27 \pm 5,4 \mathrm{~g})$; karbohidrat sederhana $(63,86 \pm 13,67 \mathrm{~g}$ vs $49,35 \pm 11,81 \mathrm{~g})$; sayur dan buah (42,61 $\pm 20,17 \mathrm{~g}$ vs $53,48 \pm 23,47 \mathrm{~g})$; serta lingkar pinggang $(88,88 \pm 9,08 \mathrm{~cm}$ vs $86,21 \pm 7,8 \mathrm{~cm})$. Hasil analisis multivariat menunjukkan jumlah konsumsi ikan tidak berhubungan bermakna $(\mathrm{p}>0,05)$ sedangkan metode memasak berhubungan bermakna terhadap kejadian dislipidemia $(\mathrm{OR}=10,84 ; \mathrm{p}<0,05)$. Simpulan: Tidak terdapat pengaruh yang bermakna antara jumlah konsumsi ikan dengan kejadian dislipidemia Namun, metode memasak yang tidak sesuai anjuran dapat meningkatkan risiko terkena dislipidemia sebesar 10,84 kali.
\end{abstract}

KATA KUNCI: konsumsi ikan, omega 3, metode memasak, dislipidemia

\section{PENDAHULUAN}

Saat ini, penyakit degeneratif dan kardiovaskuler merupakan salah satu masalah kesehatan masyarakat di Indonesia. Berdasarkan hasil Survei Kesehatan Rumah

\footnotetext{
Politeknik Kesehatan Kementerian Kesehatan Kalimantan Timur, Jl. Woltermongonsidi No.38, Samarinda, e-mail: farida.nailufar26@gmail.com Instalasi Gizi Rumah Sakit Umum Pusat Dr. Sardjito, Jl. Kesehatan No 1, Yogyakarta 55281,e-mail: martalena_purba@yahoo.com

3 Program Studi Gizi Kesehatan, Fakultas Kedokteran Universitas Gadjah Mada, Jl. Farmako, Sekip Utara, Yogyakarta 55281,e-mail: emy_huriyati@yahoo.com
} 
Tangga (SKRT) tahun 2001 menunjukkan bahwa penyakit jantung dan pembuluh darah menduduki urutan pertama sebagai penyebab kematian di Indonesia, yaitu sebesar 26,3\% kematian (1). Aterosklerosis merupakan dasar penyakit kardiovaskuler. Salah satu faktor risiko utama aterosklerosis adalah dislipidemia. Dislipidemia adalah kelainan metabolisme lipid yang ditandai dengan peningkatan maupun penurunan fraksi lipid dalam plasma. Kelainan fraksi lipid yang utama adalah kenaikan kadar kolesterol total, kolesterol low density lipoprotein (LDL), dan trigliserida, serta penurunan kolesterol high density lipoprotein (HDL) (2).

Sebuah penelitian epidemologi membuktikan keterkaitan antara konsumsi ikan dengan penurunan risiko kematian akibat penyakit jantung. Penelitian yang dilakukan terhadap bangsa Eskimo menunjukkan bahwa penduduk setempat jarang yang terkena penyakit jantung dan ternyata bangsa Eskimo banyak mengkonsumsi ikan sebesar 300 - $400 \mathrm{~g} /$ hari (3). Mengkonsumsi ikan dengan jumlah 200-400 g/minggu dapat menurunkan risiko terkena serangan jantung sebesar 20-30\% (4). Beberapa penelitian observasional lain juga menunjukkan hasil bahwa dengan mengkonsumsi ikan sebanyak 1-2 kali/ minggu atau 30-60 g/hari berhubungan dengan penurunan risiko terkena penyakit jantung koroner (PJK) sebesar 20-30\% (5).

Kota Samarinda adalah daerah yang tidak memiliki wilayah laut, tetapi sektor perikanan di Samarinda ditopang keberadaan Sungai Mahakam dan budidaya karamba. Masyarakatnya pun terkenal sangat gemar mengkonsumsi ikan. Hal ini didukung oleh data dari Dinas Perikanan tahun 2006 yang menyebutkan bahwa rerata konsumsi ikan masyarakat Samarinda sekitar $28 \mathrm{~kg} /$ jiwa/tahun atau sama dengan $500 \mathrm{~g} / \mathrm{minggu}$ (6) sedangkan standar konsumsi nasional hanya $26 \mathrm{~kg} / \mathrm{jiwa} /$ tahun (7). Sementara itu, prevalensi penyakit jantung dan pembuluh darah di Kota Samarinda merupakan yang tertinggi jika dibandingkan dengan kota atau kabupaten lain di Kalimantan Timur yaitu sebesar 12,8\% (kisaran 2,1-12,8\%) (8).

Konsumsi ikan yang tinggi tetapi diolah dengan cara digoreng, tidak menunjukkan adanya hubungan dengan penurunan risiko ischemic heart disease (IHD) (9). Asam lemak omega 3 yang terkandung dalam ikan mudah sekali mengalami kerusakan akibat pemanasan seperti penggorengan akibat proses oksidasi. Konsumsi ikan yang diolah dengan cara dipanggang atau dikukus yang menghasilkan penurunan risiko hingga 49\% (10). Pengolahan ikan dengan metode merebus memiliki persentase lemak dan asam lemak tak jenuh ganda atau polyunsaturated fatty acid (PUFA) omega 3 yang tidak berbeda nyata dengan ikan segar (11). Mengingat konsumsi ikan yang tinggi pada masyarakat Samarinda diikuti dengan prevalensi penyakit jantung dan pembuluh darah yang tinggi pula. Oleh karena itu, tujuan penelitian ini dilakukan untuk mengetahui pengaruh jumlah konsumsi ikan dan metode memasak terhadap kejadian dislipidemia.

\section{BAHAN DAN METODE}

Penelitian ini merupakan jenis penelitian observasional dengan desain kasus kontrol (case-control study) yang dilaksanakan pada bulan Oktober sampai Desember 2010. Penelitian dilakukan di Laboratorium Prodia Kota Samarinda dengan pertimbangan bahwa laboratorium tersebut adalah salah satu laboratorium terbesar di Kota Samarinda dengan kunjungan rata-rata 800-1000 pasien per bulan dan belum pernah dilakukan penelitian serupa.

Subjek penelitian ini adalah semua pasien pengunjung Laboratorium Prodia Kota Samarinda. Kasus adalah pasien yang memeriksakan dirinya ke Laboratorium Prodia dan mempunyai kadar kolesterol total di atas $200 \mathrm{mg} / \mathrm{dl}$, LDL di atas $130 \mathrm{mg} / \mathrm{dl}$, HDL di bawah $40 \mathrm{mg} / \mathrm{dl}$, dan atau trigliserida di atas $150 \mathrm{mg} /$ dl; laki-laki maupun perempuan berusia 30-60 tahun; tidak memiliki gangguan hati, ginjal, tiroid, dan diabetes mellitus (DM) berdasarkan pemeriksaan dokter; serta bersedia berpartisipasi dalam penelitian. Kontrol adalah pasien yang tidak menyandang dislipidemia yang ditentukan berdasarkan pemeriksaan laboratorium yang menunjukkan nilai profil lipid normal serta disetarakan dengan kasus berdasarkan jenis kelamin dan usia.

Metode pengambilan sampel dengan non probability sampling jenis consecutive sampling. Besar sampel ditentukan menggunakan rumus sampel untuk studi kasus kontrol berpasangan (12) dengan perkiraan 
OR $(\mathrm{R})$ sebesar 2; nilai kemaknaan $(\alpha)$ sebesar 0,05 ; power $(\beta)$ sebesar $80 \%$ sehingga diperoleh hasil $\mathrm{n} 1=\mathrm{n} 2$ $=76$. Artinya, 76 subjek untuk kelompok kasus dan 76 subjek untuk kelompok kontrol sehingga jumlah seluruh subjek penelitian sebanyak 152 orang.

Variabel independen adalah jumlah konsumsi ikan dan metode memasak ikan sedangkan variabel dependen adalah dislipidemia. Sementara itu, variabel luar meliputi konsumsi SFA (cut off point 10\% AKG), konsumsi karbohidrat sederhana (cut off point $10 \% \mathrm{AKG}$ ), konsumsi sayur dan buah (cut off point $30 \mathrm{~g} /$ hari) $(13,14)$, lingkar pinggang (cut off point wanita $80 \mathrm{~cm}$, pria $90 \mathrm{~cm}$ ) (15), status gizi berdasarkan indeks massa tubuh (cut off point $\mathrm{IMT}=23 \mathrm{~kg} / \mathrm{m}^{2}$ ) (15), kebiasaan berolahraga, dan kebiasaan merokok.

Data karakteristik subjek diperoleh melalui wawancara langsung dengan bantuan kuesioner yang meliputi nama; alamat; jenis kelamin; usia; pekerjaan; pendidikan dibedakan menjadi dua yaitu rendah (SD, SMP, SMA) dan tinggi (PT); kebiasaan berolahraga dikategorikan ya atau teratur (2-3 kali/minggu) dan tidak teratur ( $<2-3$ kali perminggu); serta kebiasaan merokok.

Data jumlah konsumsi ikan, asupan SFA, karbohidrat sederhana, serta konsumsi sayur dan buah dikumpulkan melalui wawancara menggunakan formulir semi quantitative food frequency questionare (SQFFQ) yang sebelumnya telah diujicobakan dan diuji validitas dengan hasil semua data valid dan reabilitasnya tinggi. Jumlah konsumsi ikan dikategorikan baik apabila konsumsi ikan lebih dari atau sama dengan $200 \mathrm{~g} /$ minggu dan dikategorikan tidak baik apabila konsumsi ikan kurang dari $200 \mathrm{~g} /$ minggu (4).

Metode memasak dibagi menjadi dua yaitu teknik memasak basah (merebus, menumis, mengukus) dan teknik memasak panas kering (memanggang, membakar di atas arang, menggoreng). Dengan demikian, metode memasak dikategorikan tidak sesuai anjuran apabila lebih banyak menggunakan teknik memasak kering terutama menggoreng dengan frekuensi lebih dari 3 kali/minggu sedangkan metode memasak dikategorikan sesuai anjuran apabila lebih banyak menggunakan teknik memasak basah (direbus atau dikukus) dan lebih sedikit menggunakan teknik menggoreng dengan frekuensi kurang dari 3 kali/minggu (8). Data keterangan metode memasak ikan diperoleh peneliti dengan melakukan wawancara mendalam (indepth interview).
Subjek dikategorikan dislipidemia apabila kolesterol total lebih dari $200 \mathrm{mg} / \mathrm{dl}$ (trigliserida, HDL, dan LDL normal); atau trigliserida lebih dari $150 \mathrm{mg} / \mathrm{dl}$ (kolesterol, HDL, dan LDL normal); atau HDL kurang dari $40 \mathrm{mg} / \mathrm{dl}$ (kolesterol, trigliserida, dan LDL normal); atau LDL lebih dari $130 \mathrm{mg} / \mathrm{dl}$ (kolesterol, trigliserida, dan HDL normal) $(13,14)$. Data antropometri yaitu berat badan, tinggi badan, dan lingkar pinggang diukur menggunakan timbangan injak dengan ketelitian 0,1 $\mathrm{kg}$, microtoise serta pita ukur dengan ketelitian $0,1 \mathrm{~cm}$. Data dikumpulkan oleh dua orang enumerator dengan kualifikasi tenaga lulusan S1 Gizi yang telah dilatih.

Uji statistik yang digunakan adalah uji Chi-Square untuk melihat pengaruh jumlah konsumsi dan metode memasak ikan terhadap kejadian dislipidemia sedangkan untuk melihat rerata konsumsi variabel yang berpengaruh terhadap kejadian dislipidemia menggunakan uji t. Selanjutnya, analisis multivariat dengan regresi logistik ganda dilakukan untuk melihat faktor risiko variabel bebas (jumlah konsumsi dan metode memasak ikan) terhadap variabel terikat (dislipidemia). Sebelum melakukan uji multivariat, terlebih dahulu dilakukan penyaringan variabel perancu dengan melihat nilai $p$ masing-masing variabel yang telah diuji secara bivariat dengan variabel terikat. Variabel bebas yang masuk model untuk uji multivariat adalah variabel dengan nilai p kurang dari 0,25. Sebelum dilakukan penelitian, subjek diberi penjelasan mengenai tujuan penelitian dan apabila subjek menyetujui menjadi responden, maka subjek dapat mengisi dan menandatangani surat pernyataan yang telah dibuat oleh peneliti. Semua data responden dijaga kerahasiaannya oleh peneliti.

\section{HASIL}

Subjek penelitian ini berusia antara 30-60 tahun dengan kelompok umur terbanyak antara 46-60 tahun yaitu $64,5 \%$ (49 orang) pada kasus dan $60,5 \%$ (46 orang) pada kontrol. Jenis kelamin antara kedua kelompok sama karena telah dilakukan matching. Sebagian besar subjek pada kedua kelompok memiliki tingkat pendidikan tinggi dan bekerja. Sebagian besar subjek juga tidak memiliki kebiasaan merokok dan tidak berolahraga secara teratur. Kedua kelompok baik kasus $(67,1 \%)$ maupun 
Farida Nailufar, dkk: Jumlah konsumsi dan metode memasak ikan terhadap kejadian dislipidemia

Tabel 1. Karakteristik subjek penelitian

\begin{tabular}{|c|c|c|c|c|c|}
\hline \multirow{2}{*}{ Variabel } & \multicolumn{2}{|c|}{ Kasus } & \multicolumn{2}{|c|}{ Kontrol } & \multirow{2}{*}{$\mathbf{p}$} \\
\hline & $n=76$ & $\%$ & $n=76$ & $\%$ & \\
\hline \multicolumn{6}{|l|}{ Umur (tahun) } \\
\hline $30-45$ & 27 & 35,5 & 30 & 39,5 & 0,615 \\
\hline $46-60$ & 49 & 64,5 & 46 & 60,5 & \\
\hline \multicolumn{6}{|l|}{ Jenis kelamin } \\
\hline Laki-laki & 38 & 50 & 38 & 50 & 1,000 \\
\hline Perempuan & 38 & 50 & 38 & 50 & \\
\hline \multicolumn{6}{|l|}{ Pendidikan } \\
\hline Rendah & 2 & 2,6 & 3 & 3,9 & 0,649 \\
\hline Tinggi & 74 & 97,4 & 73 & 96,1 & \\
\hline \multicolumn{6}{|l|}{ Pekerjaan } \\
\hline Bekerja & 66 & 86,8 & 62 & 81,6 & 0,374 \\
\hline Tidak bekerja & 10 & 13,2 & 14 & 18,4 & \\
\hline \multicolumn{6}{|l|}{ Merokok } \\
\hline Ya & 25 & 32,9 & 16 & 21,1 & $0,048^{*}$ \\
\hline Tidak & 51 & 67,1 & 60 & 78,9 & \\
\hline \multicolumn{6}{|l|}{ Kebiasaan olahraga } \\
\hline Tidak & 48 & 63,2 & 44 & 57,9 & 0,408 \\
\hline Ya & 28 & 36,8 & 32 & 42,1 & \\
\hline \multicolumn{6}{|l|}{ IMT } \\
\hline Tidak baik $\left(\geq 23 \mathrm{~kg} / \mathrm{m}^{2}\right)$ & 51 & 67,1 & 45 & 59,2 & 0,113 \\
\hline Baik $\left(<23 \mathrm{~kg} / \mathrm{m}^{2}\right)$ & 25 & 32,9 & 31 & 40,8 & \\
\hline \multicolumn{6}{|l|}{ Lingkar pinggang } \\
\hline $\begin{array}{l}\text { Tidak normal } \\
\text { (wanita }>80 \mathrm{~cm} \text {, pria }>90 \mathrm{~cm} \text { ) }\end{array}$ & 58 & 76,3 & 37 & 48,7 & $0,000 *$ \\
\hline $\begin{array}{l}\text { Normal } \\
\text { (wanita }<80 \mathrm{~cm} \text {, pria }<90 \mathrm{~cm} \text { ) }\end{array}$ & 18 & 23,7 & 39 & 51,3 & \\
\hline \multicolumn{6}{|l|}{ Konsumsi karbohidrat sederhana } \\
\hline Tidak baik (>10\% AKG) & 56 & 73,7 & 24 & 31,5 & $0,000^{*}$ \\
\hline Baik $(\leq 10 \%$ AKG $)$ & 20 & 26,3 & 52 & 68,5 & \\
\hline \multicolumn{6}{|l|}{ Konsumsi SFA } \\
\hline Tidak baik (>10\% AKG) & 60 & 78,9 & 17 & 22,3 & $0,000^{*}$ \\
\hline Baik $(\leq 10 \%$ AKG $)$ & 16 & 21,1 & 59 & 77,7 & \\
\hline \multicolumn{6}{|l|}{ Konsumsi sayur dan buah } \\
\hline Tidak baik $(<30 \mathrm{~g} /$ hari $)$ & 23 & 30,3 & 12 & 15,8 & $0,000^{*}$ \\
\hline Baik ( $\geq 30 \mathrm{~g} /$ hari) & 53 & 69,7 & 64 & 84,2 & \\
\hline
\end{tabular}

Keterangan: $\mathrm{IMT}=$ indeks massa tubuh; $\mathrm{AKG}=$ angka kecukupan gizi; $\mathrm{SFA}=$ saturated fatty acid; $*$ = bermakna uji Chi-Square $(\mathrm{p}<0,05)$

kontrol $(59,2 \%)$ memiliki status gizi lebih (IMT $\geq 23$ $\left.\mathrm{kg} / \mathrm{m}^{2}\right)(\mathrm{p}>0,05)$. Konsumsi karbohidrat sederhana pada kelompok kasus lebih banyak yang tidak baik (73,7\%) dibandingkan kelompok kontrol yang lebih banyak tergolong baik $(68,5 \%)(\mathrm{p}=0,000)$. Demikian juga pada konsumsi SFA kelompok kasus lebih banyak yang tidak baik $(78,9 \%)$ dan sebaliknya kelompok kontrol lebih banyak yang baik $(77,7 \%)(p=0,000)$. Sebagian besar konsumsi sayur dan buah pada kelompok kasus maupun kelompok kontrol tergolong baik yaitu sebesar 69,7\% dan $84,2 \%$ ( $p=0,000)$. Pada kelompok kasus, persentase subjek dengan lingkar pinggang yang normal sebesar 23,7\%, lebih sedikit dibandingkan kelompok kontrol $(51,3 \%)(p=0,000)$ (Tabel 1).

Rerata jumlah konsumsi ikan pada kelompok kasus sebesar 164,86 $\pm 63,61$ g sedangkan pada kelompok kontrol sebesar 218,55 $\pm 62,21 \mathrm{~g}(\mathrm{p}<0,05)$. Rerata asupan SFA pada kelompok kasus lebih tinggi dibandingkan 
Farida Nailufar, dkk: Jumlah konsumsi dan metode memasak ikan terhadap kejadian dislipidemia

Tabel 2. Kadar fraksi lipid pada kelompok kasus dan kontrol

\begin{tabular}{lccc}
\hline \multirow{2}{*}{ Kadar Lipid } & Kasus & Kontrol & \multirow{2}{*}{ p } \\
\cline { 2 - 3 } & Rerata \pm SD & Rerata \pm SD & \\
\hline Kolesterol $(\mathrm{mg} / \mathrm{dl})$ & $238,80 \pm 24,83$ & $173,32 \pm 19,72$ & $0,000^{*}$ \\
Trigliserida $(\mathrm{mg} / \mathrm{dl})$ & $150,75 \pm 44,10$ & $121,86 \pm 22,84$ & $0,000^{*}$ \\
HDL $(\mathrm{mg} / \mathrm{dl})$ & $38,96 \pm 4,80$ & $41,60 \pm 5,02$ & $0,001^{*}$ \\
LDL $(\mathrm{mg} / \mathrm{dl})$ & $141,73 \pm 24,31$ & $113,22 \pm 13,37$ & $0,000^{*}$ \\
\hline
\end{tabular}

Keterangan: * = bermakna uji $\mathrm{t}(\mathrm{p}<0,05) ; \mathrm{HDL}=$ high density lipoprotein; $\mathrm{LDL}=$ low density lipoprotein

Tabel 3. Pengaruh jumlah konsumsi dan metode memasak ikan terhadap kejadian dislipidemia

\begin{tabular}{lcccccc}
\hline \multirow{2}{*}{ Variabel } & \multicolumn{2}{c}{ Kasus } & \multicolumn{2}{c}{ Kontrol } & OR & \multirow{2}{*}{$\mathbf{p}$} \\
\cline { 2 - 5 } & $\mathbf{n}$ & $\mathbf{\%}$ & $\mathbf{n}$ & $\mathbf{\%}$ & $\mathbf{( 9 5 \%} \mathbf{C I})$ & \\
\hline Jumlah konsumsi ikan & & & & & & \\
$\quad$ Tidak baik $(<200 \mathrm{~g} /$ minggu) & 35 & 46,1 & 18 & 23,7 & 3,98 & 0,000 \\
$\quad$ Baik $(\geq 200 \mathrm{~g} /$ minggu $)$ & 41 & 53,9 & 58 & 76,3 & $1,985-7,982$ & \\
Metode memasak & & & & & & \\
$\quad$ Tidak sesuai anjuran & 54 & 71,1 & 10 & 13,2 & 12,29 & \multirow{2}{*}{0,000} \\
$\quad$ Sesuai anjuran & 22 & 28,9 & 66 & 86,8 & $5,590-27,003$ & \\
\hline
\end{tabular}

kelompok kontrol yaitu berturut-turut sebesar 34,58 \pm $5,82 \mathrm{~g}$ vs $28,27 \pm 5,4 \mathrm{~g}(\mathrm{p}<0,05)$. Demikian juga untuk asupan karbohidrat sederhana pada kelompok kasus yang lebih tinggi dibandingkan kontrol $(63,86 \pm 13,67 \mathrm{~g}$ vs $49,35 \pm 11,81 \mathrm{~g} ; \mathrm{p}<0,05)$. Sebaliknya, rerata asupan sayur dan buah pada kelompok kasus lebih kecil dibandingkan kelompok kontrol $(42,61 \pm 20,17 \mathrm{~g}$ vs $53,48 \pm 23,47 \mathrm{~g}$; $\mathrm{p}<0,05)$.

Berdasarkan hasil pengukuran antropometri diperoleh rerata berat badan sebesar $64,5 \pm 8,5 \mathrm{~kg}$ pada kelompok kasus dan $62 \pm 5,6 \mathrm{~kg}$ pada kontrol $(\mathrm{p}<0,05)$. Rerata hasil pengukuran tinggi badan didapatkan 159,68 $\pm 8,2 \mathrm{~cm}$ pada kasus dan $159,68 \pm 7,3$ pada kontrol $(\mathrm{p}>0,05)$. Sementara itu, rerata perhitungan indeks massa tubuh (IMT) yaitu sebesar $24,53 \pm 2,4 \mathrm{~kg} / \mathrm{m}^{2}$ pada kasus dan $23,26 \pm 1,6 \mathrm{~kg} / \mathrm{m}^{2}$ pada kontrol $(\mathrm{p}<0,05)$. Rerata kadar kolesterol, trigliserida, dan LDL pada kelompok kasus lebih tinggi dibandingkan kelompok kontrol dan sebaliknya dengan kadar HDL $(p=0,000)$ (Tabel 2).

Berdasarkan Tabel 3 terlihat bahwa sebagian besar subjek mengkonsumsi ikan dengan jumlah lebih dari 200 g/minggu baik pada kelompok kasus maupun kontrol. Namun, jumlah konsumsi ikan yang tergolong baik lebih banyak ditemukan pada kelompok kontrol dibandingkan kasus dan hasil uji Chi-Square menunjukkan pengaruh yang bermakna antara jumlah konsumsi ikan dengan kejadian dislipidemia $(\mathrm{OR}=3,98 ; \mathrm{p}=0,000)$. Sementara untuk metode memasak, diperoleh hasil bahwa metode memasak yang tidak sesuai anjuran lebih banyak ditemukan pada kelompok kasus sedangkan kelompok kontrol lebih banyak menggunakan metode memasak sesuai anjuran. Hasil uji Chi-Square juga menunjukkan pengaruh yang bermakna antara metode memasak dengan kejadian dislipidemia $(\mathrm{OR}=12,29 ; \mathrm{p}=0,000)$.

Hasil analisis Chi-Square for linear trend jumlah konsumsi ikan dengan metode memasak diperoleh bahwa jumlah subjek yang mengkonsumsi ikan dengan jumlah baik dan metode memasak sesuai anjuran sebanyak 9,7\% pada kasus dan 32,2\% pada kontrol $(\mathrm{OR}=1,00)$; konsumsi baik dan metode memasak tidak sesuai anjuran sebanyak $17,1 \%$ pada kasus dan 5,8\% pada kontrol $(\mathrm{OR}=9,44)$; konsumsi tidak baik dengan metode memasak sesuai anjuran sebanyak $7,8 \%$ pada kasus dan $7,1 \%$ pada kontrol $(\mathrm{OR}=3,56)$; serta konsumsi tidak baik dengan metode memasak tidak sesuai anjuran sebanyak $15,7 \%$ pada kasus dan 4,6\% pada kontrol $(\mathrm{OR}=10,73)(\mathrm{p}<0,05)$ (Tabel 4).

Analisis multivariat digunakan untuk mengetahui pengaruh paparan secara bersama-sama dari beberapa faktor risiko. Hasil analisis multivariat pada model akhir menunjukkan bahwa variabel yang bermakna terhadap 
Farida Nailufar, dkk: Jumlah konsumsi dan metode memasak ikan terhadap kejadian dislipidemia

Tabel 4. Pengaruh jumlah konsumsi dan metode memasak ikan terhadap kejadian dislipidemia

\begin{tabular}{|c|c|c|c|c|c|c|}
\hline \multicolumn{2}{|c|}{ Variabel } & \multicolumn{2}{|c|}{ Kasus } & \multicolumn{2}{|c|}{ Kontrol } & \multirow[b]{2}{*}{ OR } \\
\hline $\begin{array}{l}\text { Jumlah } \\
\text { konsumsi }\end{array}$ & $\begin{array}{l}\text { Metode } \\
\text { memasak }\end{array}$ & $\mathbf{n}$ & $\%$ & n & $\%$ & \\
\hline \multirow[t]{2}{*}{$\overline{\text { Baik }}$} & Sesuai & 15 & 9,7 & 49 & 32,2 & $1,00^{*}$ \\
\hline & Tidak sesuai & 26 & 17,1 & 9 & 5,8 & 9,44 \\
\hline \multirow[t]{2}{*}{ Tidak baik } & Sesuai & 12 & 7,8 & 11 & 7,1 & 3,56 \\
\hline & Tidak sesuai & 24 & 15,7 & 7 & 4,6 & 10,73 \\
\hline
\end{tabular}

Keterangan: * = reference; uji Chi-Square for linear trend

Tabel 5. Analisis multivariat regresi logistik berganda antara variabel penelitian dengan kejadian dislipidemia (model akhir)

\begin{tabular}{lcccc}
\hline \multicolumn{1}{c}{ Variabel } & B & OR & CI 95\% & p \\
\hline Metode memasak & 2,383 & 10,836 & $2,739-42,860$ & 0,001 \\
Status gizi IMT & $-4,497$ & 0,011 & $0,001-0,100$ & 0,000 \\
Konsumsi SFA & 2,825 & 16,855 & $3,286-86,438$ & 0,001 \\
Konsumsi karbohidrat sederhana & 2,805 & 16,522 & $4,405-61,965$ & 0,000 \\
Konsumsi sayur dan buah & 2,236 & 9,360 & $2,468-35,505$ & 0,003 \\
Lingkar pinggang & 1,984 & 7,272 & $1,581-33,445$ & 0,015 \\
\hline
\end{tabular}

Keterangan: $\mathrm{IMT}=$ indeks massa tubuh; $\mathrm{SFA}=$ saturated fatty acid

kejadian dislipidemia adalah metode memasak, konsumsi SFA, karbohidrat sederhana, sayur dan buah, lingkar pinggang, dan status gizi IMT. Nilai OR yang paling besar terlihat pada variabel konsumsi SFA $(\mathrm{OR}=16,86)$, kemudian diikuti konsumsi karbohidrat sederhana $(\mathrm{OR}=16,52)$, dan metode memasak $(\mathrm{OR}=10,84)$ (Tabel 5).

\section{BAHASAN}

\section{Karakteristik subjek penelitian}

Hasil penelitian ini menunjukkan bahwa tidak ada perbedaan yang bermakna antara kasus dan kontrol pada karakteristik subjek penelitian yang meliputi umur, jenis kelamin, pendidikan, pekerjaan, kebiasaan berolahraga, dan status gizi berdasarkan IMT. Sementara untuk faktor merokok, asupan karbohidrat sederhana, SFA, konsumsi sayur dan buah serta lingkar pinggang menunjukkan perbedaan yang bermakna. Meskipun tidak ada perbedaan kelompok umur antara kasus dan kontrol, tetapi kejadian dislipidemia lebih banyak terjadi pada kelompok umur 46-60 tahun dibandingkan dengan kelompok umur 30-45 tahun. Semakin tua seseorang, semakin berkurang kemampuan atau aktivitas reseptor LDL-nya. Hal ini menyebabkan LDL dalam darah meningkat sehingga risiko terjadinya aterosklerosis atau plak pada arteri meningkat. Lebih lanjut, para peneliti menjelaskan bahwa kenaikan LDL tersebut dapat pula disebabkan oleh semakin tua seseorang, semakin banyak yang menderita obesitas atau persentase lemak tubuh naik (16). Penelitian sebelumnya juga menunjukkan kelompok umur 45-55 tahun sebagai kelompok umur terbanyak penderita hiperlipidemia (11).

Persentase dislipidemia menurut jenis kelamin pada penelitian ini adalah sama. Hal ini terjadi karena peneliti melakukan matching jenis kelamin pada kelompok kasus dan kontrol sehingga tidak terlihat jenis kelamin mana yang lebih berisiko terhadap kejadian dislipidemia. Hasil penelitian ini juga menunjukkan tidak adanya perbedaan pendidikan dan pekerjaan antara kelompok kasus dan kontrol, artinya kedua kelompok memiliki pendidikan tinggi dan tergolong masyarakat sosial-ekonomi tinggi. Kelompok masyarakat dari tingkat sosial-ekonomi tinggi di daerah perkotaan juga mempunyai masalah tingginya kejadian obesitas, hipertensi, DM, dan tingginya kadar kolesterol (17). Di samping itu, orang dengan pendidikan tinggi dan berpenghasilan besar, lebih mudah mengikuti perubahan gaya hidup terutama dalam hal kebiasaan makan yang mengarah kepada makanan cepat saji (fast food) yang tinggi lemak dan rendah serat (11). 
Persentase penderita dislipidemia pada penelitian ini yang merokok lebih sedikit dibandingkan yang tidak merokok dan menunjukkan perbedaan yang bermakna antara kelompok kasus dan kontrol. Subjek pada kelompok kasus yang merokok semuanya berjenis kelamin laki-laki dan kebiasaan merokok tidak ditemukan pada jenis kelamin perempuan. Penelitian epidemiologi menunjukkan hubungan antara merokok dan infark miokard serta kematian akibat PJK. Efek utama rokok yang berperan adalah efek nikotin yang menyebabkan peningkatan tekanan darah dan frekuensi denyut jantung serta desaturasi hemoglobin $(\mathrm{Hb})$ oleh karbon monoksida (CO) yang menyebabkan gangguan difusi oksigen ke otot jantung sehingga konsumsi oksigen menurun yang dapat berakibat terjadinya infark miokard (18).

Secara keseluruhan, subjek penelitian ini tidak memiliki kebiasaan olahraga secara teratur. Persentase subjek yang memiliki kebiasaan olahraga pada kelompok kasus jumlahnya lebih sedikit dibandingkan dengan subjek pada kelompok kontrol. Hasil penelitian Harvard Alumny Study dengan jelas menunjukkan bahwa aktivitas fisik atau olahraga dapat mengurangi risiko PJK dengan meningkatkan kadar kolesterol HDL. Olahraga juga dapat membantu menurunkan kadar lemak tubuh, total kolesterol, dan LDL. Berolahraga dianjurkan tiga sampai lima kali setiap minggunya dan olahraga yang dianjurkan adalah olahraga yang bersifat aerobik atau aktivitas yang dinamis $(16,17)$. Lebih lanjut, subjek pada kelompok kasus maupun kontrol lebih banyak yang memiliki status gizi tidak baik atau lebih (IMT $\geq 23 \mathrm{~kg} / \mathrm{m}^{2}$ ) sehingga tidak menunjukkan perbedaan yang bermakna. Sebaliknya, pengukuran antropometri berdasarkan lingkar pinggang menunjukkan perbedaan bermakna antara kelompok kasus dan kontrol. Lingkar pinggang (waist circumference) lebih sensitif untuk melihat perbedaan timbunan lemak abdominal untuk mengidentifikasi faktor risiko obesitas (19).

Asupan karbohidrat sederhana pada kelompok kasus sebagian besar tergolong tidak baik (>10\% AKG). Besarnya rerata asupan karbohidrat sederhana pada kelompok kasus disebabkan oleh subjek yang sering mengkonsumsi makanan dan minuman manis seperti teh, sirup, dan kue-kue manis (pukis, bolu, martabak manis, dan cake). Demikian juga dengan asupan SFA pada kelompok kasus yang sebagian besar tergolong tidak baik ( $>10 \%$ AKG). Besarnya rerata asupan SFA pada kelompok kasus disebabkan oleh sebagian besar subjek sangat menyukai jajanan gorengan (singkong, pisang, ubi, lumpia, risoles, martabak), fast food (ayam dan kentang goreng), pisang keju, dan makanan yang menggunakan santan kental seperti nasi kuning dan lontong sayur. Minyak kelapa sawit dan santan merupakan sumber asam lemak utama pada bahan makanan di atas. Hal ini sejalan dengan penelitian mengenai pola makan laki-laki etnik Minangkabau yang mendapatkan hasil bahwa terdapat korelasi positif yang bermakna antara asupan lemak total dan asupan lemak jenuh (SFA) dengan kadar kolesterol plasma dan kolesterol LDL (20).

Lebih lanjut, konsumsi sayur dan buah pada kelompok kasus maupun kontrol sebagian besar tergolong baik ( $\geq 30 \mathrm{~g}$ /hari). Namun, subjek pada kelompok kasus yang mengkonsumsi sayur dan buah secara tidak baik, jumlahnya lebih banyak dibandingkan kelompok kontrol. Berdasarkan hasil wawancara, cara pengolahan sayur sebagian besar subjek pada kelompok kasus adalah dengan menumis, digulai (sayur santan), dan direbus (dibuat sup). Proses menumis dengan minyak goreng dan penambahan santan akan menurunkan kandungan serat pada sayuran. Kandungan serat pada sayuran yang dimasak dengan santan hanya sebesar 5,98\% jika dibandingkan dengan sayuran yang dimasak dengan air yaitu $6,4 \%$ (21). Selain itu, penambahan santan berarti juga menambahkan asam lemak jenuh atau SFA yang akan meningkatkan kadar kolesterol dan LDL (20).

\section{Pengaruh jumlah konsumsi ikan terhadap kejadian dislipidemia}

Risiko kejadian dislipidemia pada kelompok yang mengkonsumsi ikan dengan jumlah tidak baik $(<200$ gram/minggu) sebesar 3,98 kali dibandingkan kelompok yang mengkonsumsi ikan tergolong baik ( $\geq 200 \mathrm{gram} /$ minggu) $(p<0,05)$. Selain itu, terdapat perbedaan yang bermakna jumlah konsumsi ikan antara kelompok kasus dan kontrol. Namun, sebagian besar subjek pada kedua kelompok sama-sama mengkonsumsi ikan dengan jumlah lebih dari $200 \mathrm{~g} /$ minggu. Hal ini sesuai dengan data yang menyatakan bahwa masyarakat Samarinda sangat gemar mengkonsumsi ikan (6). 
Sebagai bahan pangan, ikan merupakan sumber protein, lemak, vitamin, dan mineral yang sangat baik. Keunggulan utama protein ikan adalah kelengkapan asam amino dan kemudahannya untuk dicerna (22). Selain protein, ikan banyak mengandung asam lemak bebas berantai karbon lebih dari 18. Asam lemak ikan lebih banyak mengandung ikatan rangkap atau asam lemak tak jenuh PUFA daripada mamalia. Keseluruhan asam lemak yang terdapat pada daging ikan kurang lebih 25 macam. Jumlah asam lemak jenuh 17-21\% dan asam lemak tidak jenuh $79-83 \%$ dari seluruh asam lemak yang terdapat pada daging ikan (23).

Ikan merupakan sumber alami asam lemak omega 3 yaitu eicosapentaenoat (EPA) dan docosaheksaenoat (DHA). Manfaat asam lemak omega 3 yang terbesar adalah menurunkan risiko terkena PJK $(2,3)$, menghambat penggumpalan darah, mengurangi kekentalan darah serta menurunkan resistensi insulin, kadar trigliserida, dan tekanan darah (1). Beberapa penelitian menunjukkan hubungan yang kuat antara mengkonsumsi ikan dengan menurunnya risiko terkena PJK. Konsumsi ikan sebanyak $22 \mathrm{~g} /$ hari dapat menurunkan risiko kematian akibat PJK sebesar 27\%. Konsumsi sebanyak 30-60 g/hari berhubungan dengan penurunan risiko PJK sebesar 20$30 \%$ (1,5). Sementara hasil review yang mengumpulkan 13 penelitian kohort menyimpulkan bahwa mengkonsumsi ikan dengan frekuensi $1 \mathrm{kali} /$ minggu dapat menurunkan risiko sebesar 15\%, frekuensi 2-4 kali/minggu sebesar $23 \%$, dan lebih dari $5 \mathrm{kali} /$ minggu risiko menurun sebesar $38 \%$ (24).

\section{Pengaruh metode memasak terhadap kejadian dislipidemia}

Berdasarkan hasil wawancara mendalam diperoleh beberapa metode memasak ikan pada masyarakat Samarinda yaitu dengan cara digoreng, dipanggang, dibakar, dipepes atau dikukus, digulai, dan direbus atau dibuat sup ikan. Hasil analisis menunjukkan bahwa kelompok yang menggunakan metode memasak tidak sesuai anjuran berisiko 12,29 kali mengalami dislipidemia dibandingkan kelompok yang menggunakan metode memasak sesuai anjuran $(\mathrm{p}<0,05)$. Pada kelompok kasus, lebih banyak subjek menggunakan metode memasak yang tidak sesuai anjuran (ikan lebih banyak dimasak dengan cara digoreng dan digulai) dibandingkan yang sesuai anjuran (direbus atau dikukus dan lebih sedikit menggunakan teknik menggoreng). Proses pengolahan dengan cara menggoreng atau menggulai berhubungan dengan tingginya kejadian dislipidemia. Proses menggoreng dengan panas lebih tinggi dari $180^{\circ}$ $\mathrm{C}$ dapat menyebabkan perubahan konfigurasi cis menjadi trans pada asam oleat yang terdapat pada minyak kelapa sawit. Asam lemak trans mempunyai efek hiperkolesterol sama dengan asam lemak jenuh (SFA) (25).

Selain itu, asam lemak omega 3 mudah sekali mengalami kerusakan akibat pemanasan seperti penggorengan akibat proses oksidasi. Metode menggoreng bisa menyebabkan terserapnya minyak goreng di dalam daging ikan dan lemak ikan justru terbuang keluar selama proses penggorengan (10). Mengolah ikan dengan metode direbus atau dikukus memiliki persentase lemak dan PUFA omega 3 yang tidak berbeda nyata dengan ikan segar. Sementara itu, pada pengolahan dengan metode menggoreng dengan suhu penggorengan $145-168{ }^{\circ} \mathrm{C}$, akan terjadi perubahan nyata pada semua jenis asam lemak yaitu PUFA omega 3 mengalami penurunan sedangkan SFA mengalami peningkatan. Penurunan tertinggi terjadi pada PUFA omega 3 yaitu mencapai 50\% dari keadaan segar (11).

Mengolah ikan sebaiknya dengan metode pepes, kukus, dipanggang atau dipresto. Metode memasak ini tidak menyebabkan lemak ikan terbuang percuma. Presto ikan yang lebih dikenal dengan ikan duri lunak juga bisa dijadikan alternatif cara pengolahan ikan tanpa menghilangkan nutrisinya. Cara pengolahannya pun sangat mudah yaitu dengan menambahkan garam dan bumbu serta melaui proses pemanasan dan tekanan dengan menggunakan alat yaitu pressure cooker. Hasil penelitian sebelumnya menyatakan bahwa kandungan protein pada ikan yang dipresto bahkan lebih tinggi daripada ikan segar yang belum diolah. Hal ini terjadi karena pada proses presto, penambahan garam serta suhu tinggi menyebabkan pengeluaran air dari daging ikan sehingga protein lebih terkonsentrasi. Namun, kandungan protein dan lemak ikan yang dipresto akan semakin menurun seiring dengan bertambahnya waktu pemanasan sehingga waktu pemanasan yang dianjurkan adalah sekitar 60-120 menit (25). 


\section{Pengaruh jumlah konsumsi ikan dan metode memasak terhadap kejadian dislipidemia}

Kandungan gizi di dalam ikan sangat dipengaruhi oleh metode memasaknya. Jumlah konsumsi yang baik apabila diikuti dengan metode memasak yang tidak sesuai anjuran akan menyebabkan kandungan gizi di dalam ikan menurun atau bahkan rusak sehingga manfaat ikan akan berkurang. Hasil uji Chi-Square for linear trend menunjukkan bahwa jumlah konsumsi ikan yang baik dan metode memasak yang sesuai anjuran bukan merupakan faktor risiko terjadinya dislipidemia $(\mathrm{OR}=1,00)$; jumlah konsumsi yang baik dengan metode memasak tidak sesuai anjuran berisiko 9,44 kali; jumlah konsumsi tidak baik dengan metode memasak sesuai anjuran berisiko 3,56 kali; dan jumlah konsumsi tidak baik dengan metode memasak tidak sesuai anjuran berisiko 10,73 kali terhadap kejadian dislipidemia.

\section{Analisis multivariat}

Variabel jumlah konsumsi ikan pada analisis multivariat menunjukkan tidak terdapat pengaruh yang bermakna dengan kejadian dislipidemia. Hal ini berlawanan dengan penelitian di China dan Belanda yang menyatakan bahwa konsumsi ikan sebanyak $22 \mathrm{~g} /$ hari dapat menurunkan risiko kematian akibat penyakit jantung sebesar $27 \%$ sedangkan konsumsi sebanyak 30-60 g/hari berhubungan dengan penurunan risiko sebesar 30\% $(5,26)$. Hubungan mengkonsumsi ikan dengan penurunan risiko penyakit jantung terdapat pada kandungan asam lemak omega 3 pada ikan. Manfaat terbesar dari asam lemak omega 3 adalah menurunkan risiko penyakit jantung. Namun, kandungan omega 3 pada ikan tidak sama dan sangat dipengaruhi oleh jenis ikan, musim, cara memasak, dan penyimpanannya. Jenis ikan yang kaya akan asam lemak omega 3 biasanya adalah ikan yang hidup di laut pada daerah beriklim dingin sedangkan ikan yang berasal dari air tawar juga mengandung asam lemak omega 3 tetapi dengan jumlah yang lebih sedikit.

Beberapa jenis ikan yang paling sering dikonsumsi oleh masyarakat Samarinda adalah ikan gabus, patin, nila, bawal, kembung, dan ikan layang. Oleh karena itu, dapat dipahami apabila variabel jumlah konsumsi ikan tidak berpengaruh bermakna terhadap kejadian dislipidemia kemungkinan karena jenis ikan yang paling banyak dikonsumsi adalah jenis ikan air tawar yang memiliki kandungan omega 3 lebih sedikit dibandingkan ikan air laut. Iklim laut di Indonesia juga bukan termasuk iklim dingin sehingga kandungan omega 3 pada ikan laut di perairan Indonesia tidak sebesar ikan yang hidup di daerah beriklim dingin. Berbeda dengan variabel metode memasak yang menunjukkan pengaruh bermakna dengan kejadian dislipidemia karena metode memasak berkaitan erat dengan pemanasan dan penambahan minyak kelapa sawit (pada proses menggoreng) atau santan (pembuatan gulai) yang dapat mengubah kandungan gizi ikan. Peneliti mendapatkan metode memasak ikan yang digunakan oleh sebagian besar subjek penelitian ini adalah dengan cara digoreng.

Status gizi berdasarkan IMT pada analisis multivariat menunjukkan adanya pengaruh dengan kejadian dislipidemia, tetapi diperoleh nilai yang negatif $(B=-4.497)$. Dengan demikian, dapat dikatakan bahwa tidak semua subjek yang mempunyai IMT tinggi mengalami dislipidemia, seperti penelitian di Amerika Serikat yang menemukan peningkatan prevalensi hiperkolesterolemia pada IMT sama dengan $25 \mathrm{~kg} /$ $\mathrm{m}^{2}$, tetapi pada IMT kurang dari $25 \mathrm{~kg} / \mathrm{m}^{2}$ peningkatan kadar kolesterol tidak konsisten (27). Hasil ini sangat berlawanan dengan penelitian-penelitian sebelumnya yang menunjukkan hubungan positif antara IMT dengan dislipidemia $(11,15,28)$.

Demikian juga dengan lingkar pinggang yang menunjukkan adanya pengaruh terhadap kejadian dislipidemia. Obesitas abdominal adalah kegemukan di daerah perut dan merupakan faktor risiko tinggi terhadap penyakit kardiovaskuler. Lemak di rongga perut diuraikan menjadi asam lemak dan gliserol yang kemudian keduaduanya masuk ke dalam sirkulasi darah. Asam lemak yang masuk ke dalam sirkulasi darah merupakan tambahan asupan lemak yang dapat mempengaruhi kadar lemak darah, yaitu trigliserida, kolesterol total, LDL, dan HDL. Perubahan kadar lemak dalam darah ini dapat menyebabkan penyakit dislipidemia (29). Para peneliti menyatakan bahwa penimbunan lemak di daerah visceral mempunyai hubungan yang lebih kuat dengan gangguan metabolik dibandingkan dengan penimbunan lemak di 
daerah subkutaneus maupun di seluruh tubuh. Hal ini disebabkan oleh asam lemak bebas yang dilepaskan dari omentum dan mesenterikum masuk lebih dahulu ke sistem vena porta sebelum masuk ke dalam sirkulasi sistemik. Kondisi ini akan berdampak besar terhadap metabolisme yang berupa gangguan metabolisme lipid sehingga terjadi peningkatan sintesis dari trigliserida hepatik yang berlanjut menjadi PJK (30).

Menurut hasil analisis multivariat, nilai OR tertinggi ditemukan pada konsumsi SFA $(\mathrm{OR}=16,86)$ Hal ini sejalan dengan penelitian di Minangkabau yang menunjukkan bahwa asupan SFA berhubungan paling bermakna dengan kadar kolesterol LDL dan subjek penelitian yang mengkonsumsi SFA lebih dari yang dianjurkan berisiko 3,723 kali memiliki kadar kolesterol LDL tinggi dibandingkan yang mengkonsumsi SFA rendah dan cukup. Bahan makanan sumber SFA umumnya diperoleh dari minyak kelapa sawit (49\% SFA) dan santan (29\% SFA) serta diolah dengan cara menggoreng dan menggulai (20).

Demikian juga dengan asupan karbohidrat sederhana yang menunjukkan pengaruh bermakna terhadap kejadian dislipidemia ( $\mathrm{OR}=16,52)$. Makanan yang terlalu tinggi karbohidrat sederhana berasosiasi dengan hiperlipidemia, berbeda dengan karbohidrat kompleks seperti zat tepung yang kurang aterogenik dibandingkan dengan bentuk karbohidrat lainnya. Penelitian sebelumnya melaporkan bahwa penggantian tepung dengan gula pada pasien hiperlipidemia dapat meningkatkan trigliserida serum, kolesterol, dan fosfolipid (31). Mengkonsumsi makanan yang tinggi karbohidrat menyebabkan terjadinya hipertrigliseridemia yang dipicu oleh sintesis hepatik dari very low density lipoprotein (VLDL) dan penurunan aktivitas lipoprotein lipase. Penelitian Puerto Rico Heart Health Program yang meneliti diit dari 8218 orang pria menunjukkan hasil bahwa terdapat hubungan yang bermakna antara konsumsi tinggi karbohidrat dengan penyakit jantung (32). Hasil dari the Nurse's Health Study juga menunjukkan bahwa wanita yang mengkonsumsi makanan yang mengandung karbohidrat sederhana tinggi, meningkatkan risiko terkena penyakit jantung (33).

Selanjutnya, konsumsi sayur dan buah juga merupakan faktor risiko yang berperan terhadap kejadian dislipidemia $(\mathrm{OR}=9,36)$. Melalui mekanisme asupan makanan, dislipidemia sering dikaitkan dengan rendahnya asupan serat makanan (sayur mayur, buahbuahan, kacang-kacangan) terutama apabila disertai dengan konsumsi makanan padat energi. Penelitian selama 20 tahun dengan lebih dari 100 ribu partisipan, membuktikan bahwa sayur dan buah bermanfaat untuk kesehatan jantung dan dapat mencegah stroke. Anjuran untuk mengkonsumsi sedikitnya 5 porsi sayur dan buah setiap harinya akan menurunkan risiko untuk menderita penyakit jantung dan stroke. Mereka yang mengkonsumsi sayur dan buah 5 porsi sehari atau lebih, risiko untuk mengalami serangan jantung dan stroke turun sebesar $12 \%$ (34). Kandungan folat, kalium, vitamin, serat, dan zat-zat fenolik yang terdapat pada sayur dan buah membantu mengurangi stres oksidatif, meningkatkan profil lipoprotein, dan regulasi hemostasis (35).

\section{SIMPULAN DAN SARAN}

Penelitian ini menunjukkan bahwa terdapat perbedaan yang bermakna jumlah konsumsi ikan antara kelompok kasus dan kontrol $(164,86 \pm 63,61 \mathrm{~g}$ vs $218,55 \pm 62,21 \mathrm{~g})$. Namun, tidak terdapat pengaruh yang bermakna antara jumlah konsumsi ikan terhadap kejadian dislipidemia. Pengaruh yang bermakna terdapat pada metode memasak dengan kejadian dislipidemia. Risiko kejadian dislipidemia lebih besar 10,83 kali pada subjek dengan metode memasak yang tidak sesuai anjuran.

Mengkonsumsi sejumlah besar ikan tanpa diikuti metode memasak yang sesuai tidak akan berpengaruh terhadap kejadian dislipidemia. Namun, metode memasak tetap harus diperhatikan yaitu dengan cara meminimalkan mengolah ikan dengan cara digoreng dan menghindari pemakaian minyak goreng secara berulang-ulang. Memasak ikan sebaiknya dengan cara dikukus atau dipepes, dibuat sup (direbus) atau dipresto karena metode ini tidak menyebabkan lemak omega 3 pada ikan terbuang percuma. Kejadian dislipidemia juga berhubungan bermakna dengan asupan SFA, asupan karbohidrat sederhana, serta asupan sayur dan buah sehingga mengkonsumsi bahan makanan yang tinggi SFA dan karbohidrat sederhana seperti makanan gorengan, makanan dan minuman manis sebaiknya dibatasi serta lebih memperbanyak konsumsi sayur dan buah untuk membantu menurunkan kadar kolesterol dalam darah. 


\section{RUJUKAN}

1. Tim Survei Kesehatan Nasional. Laporan studi mortalitas: pola penyakit penyebab kematian di Indonesia. Jakarta: Badan Penelitian dan Pengembangan Kesehatan; 2002.

2. Mansjoer A. Kapita selekta kedokteran. edisi ketiga. Jakarta: Media Aesculapius, Fakultas Kedokteran UI; 2001.

3. Bang HO, Dyerberg J, Sinclair HM. The composition of the Eskimo food in north western Greenland. Am J Clin Nutr 1980;33(12):2657-61.

4. Iso H, Kobayashi M, Ishihara J, Sasaki S, Okada K, Kita $\mathrm{Y}$, Kokubo Y, Tsugane S. Intake of fish and $\mathrm{n} 3$ fatty acids and risk of coronary heart disease among Japanese: The Japan Public Health Center-Based (JPHC) Study Cohort I. Circulation 2006;113(2):195-202.

5. Yuan JM, Ross RK, Gao YT, Yu MC. Fish and shellfish consumption in relation ti death from myocardial infarction among men in Shanghai China. Am J Epidemiol 2001;154(9):809-16.

6. Diwansyah. Pasokan ikan Samarinda stabil. [serial online] 2006 [cited 2010 Nov 9]. Available from: URL: http.//www. sapos.co.id/berita/index.asp?IDKategori $=300 \& i d=73$.

7. Balai Penelitian dan Pengembangan Kesehatan Departemen Kesehatan Republik Indonesia. Riset kesehatan dasar 2007. Laporan Nasional Kalimantan Timur. Jakarta: Departemen Kesehatan RI; 2007.

8. Mozaffarian D, Lemaitre RN, Kuller LH, Burke GL, Tracy RP, Siscovick DS. Cardiac benefits of fish consumption may depend on the type of fish meal consumed: The Cardiovascular Health Study. Circulation 2003;107(10):1372-7.

9. Chung H, Nettleton JA, Lemaitre RN, Barr RG, Tsai MY, Tracy RP, Siscovick DS. Frequency and type of seafood consumed influence plasma (n-3) fatty acid concentrations. J Nutr 2008;138(12):2422-7.

10. Sulistyowati W. Perubahan profil asam lemak omega 3 pada Lemuru (Sardinella longiceps) dan Nila Merah (Oreochromis sp.) karena proses perebusan dan penggorengan [Tesis]. Surabaya: Program Pascasarjana Universitas Airlangga; 2001.

11. Waspadji S, Sukardji K. Pengkajian status gizi studi epidemiologi dan penelitian di rumah sakit. Jakarta: Balai Penerbit FKUI; 2010.

12. Sastroasmoro $S$, Ismael S. Dasar-dasar metodologi penelitian klinis. Jakarta: Penerbit Binarupa Aksara; 2002.

13. National Cholesterol Education Program (NCEP). Detection, evaluation and treatment of high blood cholesterol in adults (adults treatment panel III). National Institutes of Health Publication No 02-5215; 2002.

14. Perkeni. Petunjuk praktis penatalaksanaan dislipidemia. Jakarta: PB Perkeni; 2004.
15. Lipoeto NI. Zat gizi dan makanan pada penyakit kardiovaskuler. Padang: Andalas University Press; 2006.

16. Ashton WB, Nanchahal K, Wood DA. Body mass index and metabolic risk factor for coronary heart disease in women. Eur Heart J 2001;22(1):46-55.

17. Soeharto I. Serangan jantung dan stroke. Jakarta: Gramedia Pustaka Utama; 2004.

18. Siregar FA, Harahap A, Rasmaliah. Analisa faktor risiko penyakit jantung koroner penderita rawat jalan Rumah Sakit Dr Pringadi Medan. Info Kesehatan Masyarakat 2005;9(1):14-8.

19. Zhu S, Wang Z, Heshka S, Heo M, Faith MS, Heymsfield SB. Waist circumference and obesity-associated risk factors among whites in the third National Health and Nutrition Examination Survey: clinical action thresholds. Am J Clin Nutr 2002;76(4):743-9.

20. Sulastri D, Rahayuningsih S, Purwantyastuti. Pola asupan lemak, serat dan antioksidan serta hubungannya dengan profil lipid pada laki-laki etnik Minangkabau. Majalah Kedokteran Indonesia 2005;55(2):61-6.

21. Khomsan A. Pangan dan gizi untuk kesehatan. Jakarta: PT RajaGrafindo Persada; 2004.

22. Astawan M. Ikan air tawar kaya protein \& vitamin. [serial online] 2005 [cited 2010 Juli 20]. Available from: URL: http.//web.ipb.ac.id/ tpg/de/pubde_tknprcss_ikan.php

23. Hartono A. Terapi gizi dan diet rumah sakit. Jakarta: Penerbitan Buku Kedokteran EGC; 2006.

24. He K, Song Y, Daviglus ML, Liu K, Van Horn L, Dyer AR, Greenland P. Accumulated evidence on fish consumption and coronary heart disease mortality: a meta-analysis of cohort studies. Circulation 2004;109(22):2705-11.

25. Tapotubun AM, Nanlohy EEEM, Louhenapessy JM. Efek waktu pemanasan terhadap mutu presto beberapa jenis ikan. Ichthyos 2008;7(2):65-70.

26. Streppel MT, Ocké MC, Boshuizen HC, Kok FJ, Kromhout D. Long-term fish consumption and n-3 fatty acid intake in relation to (sudden) coronary heart disease death: the Zutphen study. Eur Heart J 2008;29(16):2024-30.

27. Jousilahti P, Vartiainen E, Tuomilehto J, Puska P. Twenty-year dynamics of serum cholesterol in middleaged population of eastern Finland. Ann Intern Med 1996;125(9):713-22.

28. Brown CD, Higgins M, Donato KA, Rohde FC, Garrison R, Obarzanek E, Ernst ND, Horan M. Body mass index and the prevalence of hypertension and dyslipidemia. Obes Res 2000;8(9):605-19.

29. Wiramiharja K. Obesitas dan penanggulangannya. Bandung: Granada; 2004.

30. McFarlane SI, Banerji M, Sowers JR. Insulin resistance and cardiovascular disease. J Clin Endocrinol Metab 2001;86(2):713-8. 
31. Waspadji S, Sukardji K. Asupan energi dan beberapa zat gizi pada penderita hiperlipidemia. Jakarta: Balai Penerbit FKUI; 2003.

32. Liu S. Intake of refined carbohydrates and whole grain foods in relation to risk of type 2 diabetes mellitus and coronary heart disease. J Am Coll Nutr 2002;21(4):298-306.

33. Howard BV, Wylie-Rosett J. Sugar and cardiovascular disease: a statement for healthcare professionals from the Committee on Nutrition of the Council on Nutrition,
Physical Activity, and Metabolism of the American Heart Association. Circulation 2002;106(4):523-7.

34. Liu S, Manson JE, Lee IM. Fruit and vegetable intake and risk of cardiovascular disease: the woman's health study. Am J Clin Nutr 2000;72(4):922-8.

35. Dauchet L, Amouyel P, Hercberg S, Dallongeville J. Fruit and vegetable consumption and risk of coronary heart disease: a meta-analysis of cohort studies. J Nutr 2006;136(10):2588-93. 